\title{
ANALISIS REDUPLIKASI PADA TEKS KARANGAN SISWA KELAS VIII SMP NEGERI 1 CIBADAK
}

\author{
Firdani Nur Hikmatilah \\ Universitas Muhammadiyah Sukabumi \\ firdaninur@gmail.com
}

\begin{abstract}
Abstrak. Proses morfologi merupakan proses pembentukan kata-kata dari satuan lain yang merupakan sebuah bentuk dasarnya. Dalam proses morfologi terdapat reduplikasi. Reduplikasi adalah proses pembentukan kata yang mengalami pengulangan pada setiap kata dasarnya. Hasil pengulangan tersebut berupa kata ulang, sedangkan satuan yang diulang merupakan bentuk dasar. Reduplikasi terdiri dari empat macam diantaranya yaitu reduplikasi seluruh, reduplikasi sebagian, reduplikasi yang berkombinasi dengan proses pembubuhan afiks, dan reduplikasi dengan perubahan fonem. Dalam proses pengulangan kata atau reduplikasi berkaitan dengan bahasa tulis yang dilakukan dengan menulis atau mengarang, seperti halnya pada teks karangan siswa yang terdiri dari lima teks karangan, yaitu teks deskripsi, teks narasi, teks argumentasi, teks persuasi, dan teks eksposisi yang didalamnya terdapat kata reduplikasi. Tujuan penelitian ini yaitu untuk mengetahui reduplikasi pada setiap teks karangan siswa kelas VIII SMP Negeri 1 Cibadak. Desain penelitian yang dilakukan dalam penelitian ini yaitu desain penelitian deskripstif kualitatif. Data yang didapatkan berupa teks karangan siswa, dan dianalisis mengenai reduplikasi yang terdapat pada teks karangan siswa kelas VIII SMP Negeri 1 Cibadak. Teknik pengumpulan data yang dilakukan dalam penelitian ini yaitu observasi dan dokumentasi. Kesimpulan dari penelitian ini yaitu reduplikasi pada teks karangan siswa terdapat reduplikasi seluruh, reduplikasi sebagian, reduplikasi yang berkombinasi dengan proses pembubuhan afiks dan reduplikasi dengan perubahan fonem.
\end{abstract}

Kata kunci: reduplikasi, teks karangan siswa

Abstract. The process of morphology is the process of forming words from other units which are a basic form. In the morphological process there is reduplication. Reduplication is the process of forming words that are repeated in each of the basic words. The result of the repetition is in the form of repeated words, while the repeated units are the basic form. There are four types of reduplication, namely total reduplication, partial reduplication, reduplication in combination with the affixing process, and reduplication with phoneme changes. In the process of word repetition or reduplication related to written language, which is done by writing or composing, as is the case with student essays consisting of five essays, namely descriptive text, narrative text, argumentative text, persuasion text, and exposition text in which there are words. reduplication. The purpose of this study was to determine the reduplication of each text written by class VIII students of SMP Negeri 1 Cibadak. The research design carried out in this study is a qualitative descriptive research design. The data obtained were in the form of student texts, and were analyzed regarding the reduplication contained in the texts written by class VIII students of SMP Negeri 1 Cibadak. Data collection techniques used 
Firdani Nur Hikmatilah

Analisis Reduplikasi pada Teks Karangan Siswa Kelas VIII SMP Negeri 1 Cibadak

in this research are observation and documentation.

The conclusion of this study is that the reduplication of

the student's text contains complete reduplication,

partial reduplication, reduplication which combines

with the process of affixing affixes and reduplication with phoneme changes.

\section{PENDAHULUAN}

Keywords: reduplication, student's text

Bahasa merupakan suatu alat komunikasi yang dimiliki manusia berupa sistem lambang bunyi yang berasal dari alat ucap manusia. Bahasa digunakan oleh manusia dalam berkomunikasi baik itu berkomunikasi secara langsung maupun secara tidak langsung. Dalam berkomunikasi, terdapat faktor yang mempengaruhi komunikasi yaitu kemampuan berbahasa, kemampuan ini tidak terlepas dari komponen-komponen bahasa itu sendiri, salah satu komponennya yaitu Morfologi.

Ramlan (2009:21) morfologi merupakan ilmu bahasa yang membicarakan atau mempelajari seluk beluk bentuk kata serta pengaruh perubahan-perubahan bentuk kata terhadap golongan kata dan arti kata. Dengan kata lain, morfologi dapat diartikan sebagai cabang ilmu bahasa yang mempelajari bentuk dan proses pembentukan kata. Proses pembentukan kata tersebut dapat berpengaruh terhadap perubahan bentuk kata dan juga terhadap golongan dari arti kata tersebut.

Proses pembentukan kata atau sering disebut dengan proses morfologi yaitu proses pembentukan kata-kata dari satuan lain yang merupakan bentuk dasarnya (Ramlan, 2009:63). Salah satu proses morfologi yaitu proses reduplikasi. Reduplikasi merupakan pengulangan kata gramatikal, baik seluruhnya maupun sebagian, baik dengan variasi fonem maupun tidak. Dalam proses pengulangan kata tersebut berkaitan dengan bahasa tulis yang dilakukan dengan menulis dan mengarang suatu karangan yang menuntut siswa dalam proses mengembangkan kemampuan berpikir. Dalam menuliskan sebuah karangan tidak terlepas dari pengggunaan bahasa termasuk pada setiap kata yang terkandung di dalam teks karangan. Munculnya setiap kata dalam sebuah karangan berkaitan dengan salah satu cabang ilmu linguistik yang membahas mengenai seluk beluk bentuk kata yaitu morfologi, salah satunya yaitu pengulangan kata atau reduplikasi yang bisa kita jumpai pada beberapa teks karangan. Hal demikian terdapat dalam karangan yang dituliskan oleh siswa, termasuk siswa kelas VIII SMP Negeri 1 Cibadak.

Penelitian sebelumnya yang membahas tentang proses reduplikasi telah dilakukan oleh Anik Susilowati (2017) dengan judul Analisis Reduplikasi Pada Karangan Teks Deskripsi Siswa Kelas VII SMP Negeri 2 Gatak Sukaharjo. Dalam penelitiannya, Susilowati menemukan empat bentuk reduplikasi yang mayoritas reduplikasinya terdapat pada pengulangan dengan berimbuhan atau pembubuhan afiks, sedangkan mayoritas makna reduplikasi yangditemukan yaitu makna "banyak" dan makan "sifat" yang menggambarkan karangan deskripsi siswa kelas VII SMP Negeri 2 Gatak.

Berdasarkan penjelasan di atas, peneliti tertarik untuk menganalisis reduplikasi yang terdapat dalam teks karangan siswa. Penelitian ini berjudul "analisis reduplikasi pada teks karangan siswa kelas VIII SMP Negeri 1 Cibadak".

\section{METODE PENELITIAN}

Menurut Sugiyono (2012) mengatakan bahwa metode penelitian merupakan cara ilmiah untuk menemukan sebuah data untuk memenuhi tujuan serta dapat digunakan untuk hal tertentu. Metode penelitian yang dilakukan oleh peneliti yaitu metode penelitian kualitatif. Menurut Sugiyono (2012) metode penelitian kualitatif adalah metode penelitian yang digunakan untuk meneliti pada kondisi objek yang alamiah.

Dalam penelitian ini, metode yang digunakan ialah jenis metode penelitian deskriptif kuallitatif. Peneliti menggunakan penelitian deskriptif kualitatif untuk menjawab rumusan terkait reduplikasi yang terdapat dalam teks karang siswa kelas VIII SMP Negeri 1 Cibadak.

Sumber data dalam penelitian ini yaitu teks karangan siswa kelas VIII SMP Negeri 1 Cibadak, teknik pengumpulan data berupa observasi dan dokumentasi. Teknik analisis data berupa reduksi data, penyajian data, dan penarikan kesimpulan.

\section{HASIL PENELITIAN}

Bentuk-bentuk reduplikasi terdiri dari empat macam: reduplikasi seluruh, reduplikasi sebagian, reduplikasi yang berkombinasi dengan afiksasi dan reduplikasi dengan perubahan fonem. 
Analisis Reduplikasi pada Teks Karangan Siswa Kelas VIII SMP Negeri 1 Cibadak

1. Reduplikasi seluruh

A. Reduplikasi seluruh pada teks deskripsi

Reduplikasi seluruh pada teks deskripsi terdapat dalam kode A/VIII A, B/VIII B, C/VIII C, D/VIII D, E/VIII E, F/VIII F, G/VIII G, H/VIII H, I/VIII I.

a. Pada kode kelas A/VIII A kata reduplikasi seluruh adalah Ratarata, hari-hari, kata-kata, bukubuku, jemari-jemari, hal-hal, teman-teman, orang-orang, masing-masing, negara-negara.

b. Pada kode kelas B/VIII B kata reduplikasi seluruh adalah pohon-pohon, daun-daun, duduk-duduk, teman-teman, lari-lari, tetesan-tetesan, generasoi-generasi, tumbuhantumbuhan, ikan-ikan, orangorang, jari-jari.

c. Pada kode kelas C/VIII C reduplikasi seluruh adalah orang-orang, kucing-kucingku, sungguh-sungguh, hiasaanhiasan, foto-foto, buku-buku, rata-rata.

d. Pada kode kelas D/VIII D reduplikasi seluruh adalah jalan-jalan, sahabat-sahabatku, kenangan-kenangan.

e. Pada kode E/ VIII E reduplikasi seluruh adalah kebudayaankebudayaan, jauh-jauh, segarsegar, kios-kios, masingmasing, masing-masing

f. Pada kode F/VIII F reduplikasi seluruh adalah kebudayaankebudayaan, langit-langit.

g. Pada kode G/VIII G reduplikasi seluruh adalah Pinggir-pinggir, orang-orang, bebatuan-bebatuan

h. Pada kode H/VIII H kata reduplikasi seluruh adalah barang-barang, dinding-dinding, orang-orang, jari-jari, rempahrempah, ibu-ibu, tanamani. tanaman, jauh-jauh, paru-paru

Pada kode I/VIII

I kata reduplikasi seluruh adalah tas-tas, buku-buku, kemasankemasan, orang-orang, jari-jari.

B. Reduplikasi pada teks narasi

Reduplikasi pada teks narasi terdapat pada kode A/VIII A, B/VIII B, D/VIII D, F/VIII F, G/ VIII G, H/VIII H, dan I/VIII I. a. Pada kode A/VIII A kata reduplikasi seluruh adalah jalan-jalan, alat-alat, jendelajendela, buku-buku, kebutkebut, jalan-jalan, pagi-pagi, kios-kios, bahan-bahan.

b. Pada kode kelas B/ VIII B reduplikasi seluruh adalah teman-teman, pagi-pagi, orangorang, nama-nama, masingmasing, hari-hari, tugas-tugas, barang-barang, pohon-pohon, guru-guru, kakak-kakak, beresberes, kelas-kelas, tiba-tiba, desa-desa, pasar-pasar, bagusbagus, kata-kata, anak-anak, bunga-bunga, kerajaankerajaan.

c. Pada kode kelas D/VIII D reduplikasi seluruh adalah prajurit-prajurit, cari-cari, harihari.

d. Pada kode F/VIII F reduplikasi seluruh adalah kabut-kabut, tiba-tiba, pohon-pohon, rintikrintik, masa-masa, hari-hari, anak-anak, cucu-cucu, pagipagi, rumah-rumah, puingpuing.

e. Pada kode G/VIII G reduplikasi seluruh adalah pagipagi, sepupu-sepupu.

f. Pada kode H/VIII H reduplikasi seluruh adalah jalan-jalan, siapsiap, kira-kira, rumah-rumah, benar-benar.

g. Pada kode I/VIII I reduplikasi seluruh adalah saudarasaudaraku, macam-macam, ukiran-ukiran, foto-foto, bungabunga.

C. Reduplikasi seluruh pada teks argumentasi

Reduplikasi seluruh pada teks argumentasi dalam kode teks G/VIII $\mathrm{G}$ terdapat kata reduplikasi seluruh yaitu nilai-nilai dan faktor-faktor.

D. Reduplikasi seluruh pada teks persuasi

Reduplikasi seluruh pada teks persuasi terdapat pada kode kelas A/VIII A dan kode kelas I/VIII I

a. Pada kode kelas A/VIII A terdapat kata reduplikasi seluruh adalah remaja-remaja.

b. Pada kode kelas I/VIII I terdapat kata reduplikasi seluruh adalah orang-orang. 
E. Reduplikasi seluruh pada teks eksposisi

Reduplikasi seluruh pada teks eksposisi hanya terdapat pada kode kelas G/VIII G yaitu ikan-ikan.

2. Reduplikasi sebagian

A. Reduplikasi sebagian pada teks deskripsi

Reduplikasi sebagain pada teks deskripsi terdapat pada kode kelas A/VIII A, B/VIII B, C/VIII C, D/VIII D, F/VIII F, dan I/VIII I.

a. Pada kode kelas A/VIII A terdapat kata reduplikasi sebagian yaitu menari-nari, berjalan-jalan, bersama-sama dan bermacam-macam. Kata menari-nari dibentuk dari kata dasar menari, kata berjalanjalan dibentuk dari kata dasar berjalan, kata bersama-sama berasal dari kata dasar bersama, dan kata bermaam berasal dari kata dasar bermacam.

b. Pada kode B/VIII B terdapat kata reduplikasi sebagian yaitu menyala-nyala, perlahan-lahan, sepatut-patutnya, dan beberapa. Kata menyala-nyala berasal dari kata dasar menyala, kata perlahan-lahan berasal dari kata dasar perlahan, kata sepatutpatutnya berasal dari kata dasar sepatutnya, dan kata beberapa berasal dari kata dasar berapa.

c. Pada kode C/VIII C terdapat kata reduplikasi sebagian yaitu melambai-lambai, mengeluselus. Kata melambai-lambai berasal dari kata dasar melambai dan kata mengeluselus berasal dari kata dasar mengelus.

d. Pada kode D/VIII D terdapat kata reduplikasi sebagian yaitu seseorang dan beberapa. Kata seseorang berasal dari kata dasar seorang dan kata beberapa berasal dari kata dasar berapa.

e. Pada kode F/VIII F terdapat kata reduplikasi sebagian yaitu kata berbeda-beda, berasal dari kata dasar berbeda.

f. Pada kode I/VIII I terdapat kata reduplikasi sebagian yaitu kata beberapa dan berulang-ulang. Kata beberapa berasal dari kata dasar berapa dan kata berulangulang berasal dari kata dasar berulang.

B. Reduplikasi sebagian pada teks narasi

Reduplikasi sebagian pada teks narasi terdapat pada kode kelas A/VIII A, B/VIII B, D/VIII D,F/VIII F, dan H/VIII H

a. Pada kode kelas A/VIII A terdapat kata reduplikasi sebagian yaitu berlama-lama, berasal dari kata dasar berlama.

b. Pada kode kelas B/VIII B terdapat kata reduplikasi sebagian yaitu seseorang, bersama-sama, bermain-main, berlari-lari, berbagi-bagi, melihat-lihat, terburu-buru. Kata seseorang berasal dari kata dasar seorang, kata bersama-sama berasal dari kata dasar bersama, kata bermainmain berasal dari kata dasar bermain, kata berlari-lari berasal dari kata dasar berlari, kata berbagi-bagi berasal dari kata dasar berbagi, kata melihat-lihat berasal dari kata dasar melihat dan kata terburuburu berasal dari kata dasar terburu.

c. Kode kelas D/VIII D terdapat reduplikasi sebagian yaitu kata berliku-liku berasal dari kata dasar berliku.

d. Kode kelas F/VIII F terdapat reduplikasi sebagian yaitu kata bersama-sama dan menyalanyala. Kata bersama-sama berasal dari kata dasar bersama, kata menyala-nyala berasal dari kata dasar nyala.

e. Kode kelas H/VIII H reduplikasi sebagian yaitu melihat-lihat dan berpandangpandangan. Kata melihat-lihat berasal dari kata dasar melihat, kata berpandang-pandangan berasal dari kata dasar berpandangan.

C. Reduplikasi sebagian pada teks argumentasi

Reduplikasi sebagai pada teks argumentasi terdapat alam kode kelas G/VIII G yaitu kata beberapa berasal dari kata dasar berapa.

D. Reduplikasi sebagian pada teks persuasi 
Reduplikasi sebagian pada teks persuasi terdapat pada kode kelas A/VIII A, F/VIII F.

a. Pada kode kelas A/VIII A terdapat kata reduplikasi sebagian yaitu membedabedakan dan seseorang. Kata membeda-bedakan berasal dari kata dasar membedakan, kata seseorang berasal dari kata dasar seorang.

b. Pada kode F/VIII F terdapat kata reduplikasi sebagian yaitu bersama-sama dan beberapa. Kata bersama-sama berasal dari kata dasar bersama, kata beberapa berasal dari kata dasar berapa.

E. Reduplikasi sebagian pada teks eksposisi

Reduplikasi sebagian pada teks eksposisi terdapat dalam kode kelas G/VIII yaitu kata berhati-hati berasal dari kata dasar berhati.

3. Reduplikasi yang berkombinasi dengan afiksasi.

A. Reduplikasi

berafiksasi pada teks deskripsi Reduplikasi berafiksasi pada teks deskripsi terdapat dalam kode kelas A/VIII A, C/VIII C, D/VIII D, E/VIII E, F/VIII F, H/VIII H, I/VIII I

a. Kode kelas A/VIII A terdapat reduplikasi berafiksasi yaitu anak-anaknya dan buahbuahan, berasal dari kata dasar anak dan buah.

b. Kode kelas C/VIII C terdapat reduplikasi berafiksasi yaitu bulu-bulunya dan kukukukunya berasal dari kata dasar bulu dan kuku.

c. Kode kelas D/VIII D terdapat reduplikasi berafiksasi yaitu kata satu-satunya berasa dari kata dasar satu.

d. Kode kelas E/VIII E terdapat reduplikasi berafiksasi yaitu kata buah-buahan dan sayursayuran, berasal dari kata dasar buah dan sayur.

e. Kode kelas F/VIII F terdapat reduplikasi berafiksasi yaitu kata berlama-lama, berasal dari kata dasar lama.

f. Kode kelas H/VIII H terdapat reduplikasi berafiksasi yaitu baju-bajunya, pohon-pohonnya, rumput-rumputan, umbiumbian dan buah-buahan. Berasal dari kata dasar baju, pohon, rumput, umbi, dan buah.

g. Kode kelas I/VIII I terdapat reduplikasi berafiksasi yaitu kata obat-obatan berasal dari bentuk dasar obat.

B. Reduplikasi berafiksasi pada teks narasi

Reduplikasi berafiksasai pada teks narasi terdapat dalam kode kelas A/VIII A, B/VIII B, D/VIII D, F/VIII F, H/VIII H

a. Kode kelas A/VIII A terdapat reduplikasi berafiksasi yaitu kata bahan-bahannya, terbentuk dari kata dasar bahan.

b. Kode kelas B/VIII B terdapat reduplikasi berafiksasi yaitu kata nama-namanya, malasmalasan, sayur-sayuran dan dayang-dayangnya. Berasal dari kata dasar nama, malas, sayur dan dayang.

c. Kode kelas D/VIII D terdapat kata reduplikasi berafiksasi satu-satunya. Berasal dari kata dasar satu.

d. Pada kode kelas F/VIII F terdapat kata reduplikasi berafiksasi yaitu rasa-rasanya, mobil-mobilan dan besarbesaran. Berasal dari kata dasar rasa, mobil dan besar.

e. Pada kode kelas H/VIII H terdapat kata reduplikasi berafiksasi yaitu sepedasepedaaan, berasal dari kata dasar sepeda.

C. Reduplikasi berafiksasi pada teks persuasi

Reduplikasi berafiksasi pada teks persuasi terdapat pada kode kelas A/VIII A yaitu pada kata temantemannya.

4. Reduplikasi dengan perubaahan fonem

A. Reduplikasi dengan perubahan fonem pada teks deskripsi terdapat pada kode kelas A/VIII A, B/VIII B, dan I/VIII I

a. Pada kode kelas A/VIII A terdapat reduplikasi dengan perubahan fonem yaitu sayurmayur yang dibentuk dari kata dasar sayur. 
Firdani Nur Hikmatilah

Analisis Reduplikasi pada Teks Karangan Siswa Kelas VIII SMP Negeri 1 Cibadak

b. Pada kode kelas B/VIII B fonem yang sering muncul adalah sayurterdapat reduplikasi dengan perubahan fonem yaitu berwarna-warni yang dibentuk dari kata dasar warna.

mayur.

\section{DAFTAR PUSTAKA}

Dalman. (2013). Menulis Karya Ilmiah. PT. Radja Grafindo Perseda.

c. Pada kode kelas I/VIII I terdapat reduplikasi dengan perubahan fonem yaitu warnawarni yang dientuk dari kata dasar warna.

B. Reduplikasi dengan perubahan fonem pada teks narasi terdapat pada kode kelas A/VIII A, F/VIII F, H/VIII H dan I/VIII I

a. Pada kode kelas A/VIII A terdapat reduplikasi dengan perubahan fonem yaitu sayurmayur yang dibentuk dari kata dasar sayur.

b. Pada kode F/VIII F terdapat reduplikasi dengan perubahan fonem yaitu warna-warni dan sayur-mayur, yang dibentuk dari kata dasar sayur dan warna.

c. Pada kode H/VIII H terdapat reduplikasi dengan perubahan fonem yaitu kata bolak-balik berasal dari kata dasar balik.

d. Pada kode I/VIII I terdapat reduplikasi dengan perubahan fonem yaitu kata berwarnawarni berasal dari kata dasar warna.

\section{SIMPULAN}

Reduplikasi pada teks karangan siswa terdapat reduplikasi seluruh, reduplikasi sebagian, reduplikasi yang berkombinasi dengan afiksasi, reduplikasi dengan perubahan fonem. Reduplikasi seluruh terdapat pada kelima teks karangan; teks deskripsi, teks narasi, teks argumentasi, teks persuasi dan teks eksposisi. Kata reduplikasi seluruh yang sering muncul adalah kata jalan-jalan dan orang-orang. Reduplikasi sebagian terdapat pada kelima teks karangan; teks deskripsi, teks narasi, teks argumentasi, teks persuasi dan teks eksposisi, kata reduplikasi sebagian yang sering muncul adalah kata beberapa dan bersama-sama. Reduplikasi yang berkombinasi dengan afiksasi terdapat pada ketiga teks karanga; teks deskripsi, teks narasi, dan teks persuasi, kata reduplikasi berafiksasi yang sering muncul adalah buahbuahan dan sayur-sayuran. Reduplikasi dengan perubahan fonem terdapat pada dua teks karangan; teks deskripsi dan teks narasi. Kata reduplikasi dengan perubahan

Finoza, L. (2008). Kompisisi Bahasa Indonesia. Diksi Insan Mulia.

Keraf. (2007). Argumentasi dan Narasi Komposisi Lanjutan III. Gramedia Pustaka Utama.

Kosasih. (2017). Bahasa Indonesia (edisi revisi). Kementrian Pendidikan dan Kebudayaan.

Kridalaksana, H. (2007). Pembentukan Kata dalam Bahasa Indonesia. PT. Gramedia Pustaka Utama.

Kridalaksana, H. (2008). Kamus Linguistik. PT. Gramedia Pustaka Utama.

Ramlan. (2009). Morfologi suatu tinjauan deskriptif. CV. Karyono.

Sugiyono. (2012). Memahami Penelitian Kualitatif. Alfabeta.

Wiyanto, A. (2004). Terampil Menulis Paragraf. Gramedia Widiasarana. 